\title{
Lactate oxidative phosphorylation by annulus fibrosus cells: evidence for lactate- dependent metabolic symbiosis in intervertebral discs
}

Dong Wang ${ }^{1 \dagger}$, Robert Hartman ${ }^{1,2 \dagger}$, Chao Han ${ }^{1,3}$, Chao-ming Zhou ${ }^{1}$, Brandon Couch ${ }^{1}$, Matias Malkamaki ${ }^{1}$, Vera Roginskaya ${ }^{4}$, Bennett Van Houten ${ }^{4}$, Steven J. Mullett ${ }^{4,5}$, Stacy G. Wendell ${ }^{4,5}$, Michael J. Jurczak ${ }^{6,7}$, James Kang ${ }^{8}$, Joon Lee ${ }^{1}$, Gwendolyn Sowa ${ }^{1,9^{*}}$ and Nam Vo ${ }^{1 *}$ (D)

\begin{abstract}
Background: Intervertebral disc degeneration contributes to low back pain. The avascular intervertebral disc consists of a central hypoxic nucleus pulpous (NP) surrounded by the more oxygenated annulus fibrosus (AF). Lactic acid, an abundant end-product of NP glycolysis, has long been viewed as a harmful waste that acidifies disc tissue and decreases cell viability and function. As lactic acid is readily converted into lactate in disc tissue, the objective of this study was to determine whether lactate could be used by AF cells as a carbon source rather than being removed from disc tissue as a waste byproduct.
\end{abstract}

Methods: Import and conversion of lactate to tricarboxylic acid (TCA) cycle intermediates and amino acids in rabbit AF cells were measured by heavy-isotope $\left({ }^{13} \mathrm{C}\right.$-lactate) tracing experiments using mass spectrometry. Levels of protein expression of lactate converting enzymes, lactate importer and exporter in NP and AF tissues were quantified by Western blots. Effects of lactate on proteoglycan $\left({ }^{35} \mathrm{~S}\right.$-sulfate) and collagen ( ${ }^{3} \mathrm{H}$-proline) matrix protein synthesis and oxidative phosphorylation (Seahorse XFe96 Extracellular Flux Analyzer) in AF cells were assessed.

Results: Heavy-isotope tracing experiments revealed that AF cells imported and converted lactate into TCA cycle intermediates and amino acids using in vitro cell culture and in vivo models. Addition of exogenous lactate (4 mM) in culture media induced expression of the lactate importer MCT1 and increased oxygen consumption rate by 50\%, mitochondrial ATP-linked respiration by $30 \%$, and collagen synthesis by $50 \%$ in AF cell cultures grown under physiologic oxygen $\left(2-5 \% \mathrm{O}_{2}\right.$ ) and glucose concentration (1-5 mM). AF tissue highly expresses MCT1, LDH-H, an enzyme that preferentially converts lactate to pyruvate, and PDH, an enzyme that converts pyruvate to acetyl-coA. In contrast, NP tissue highly expresses MCT4, a lactate exporter, and LDH-M, an enzyme that preferentially converts pyruvate to lactate.

(Continued on next page)

\footnotetext{
* Correspondence: sowaga@upmc.edu; nvv1@pitt.edu

${ }^{\dagger}$ Dong Wang and Robert Hartman contributed equally to this work. 'Department of Orthopaedic Surgery, Ferguson Laboratory for Orthopedic and Spine Research, University of Pittsburgh, 200 Lothrop Street, E1644 Biomedical Science Tower, Pittsburgh, PA 15261, USA

Full list of author information is available at the end of the article
}

(c) The Author(s). 2021 Open Access This article is licensed under a Creative Commons Attribution 4.0 International License, which permits use, sharing, adaptation, distribution and reproduction in any medium or format, as long as you give appropriate credit to the original author(s) and the source, provide a link to the Creative Commons licence, and indicate if changes were made. The images or other third party material in this article are included in the article's Creative Commons licence, unless indicated otherwise in a credit line to the material. If material is not included in the article's Creative Commons licence and your intended use is not permitted by statutory regulation or exceeds the permitted use, you will need to obtain permission directly from the copyright holder. To view a copy of this licence, visit http://creativecommons.org/licenses/by/4.0/ The Creative Commons Public Domain Dedication waiver (http://creativecommons.org/publicdomain/zero/1.0/) applies to the data made available in this article, unless otherwise stated in a credit line to the data. 


\begin{abstract}
(Continued from previous page)
Conclusions: These findings support disc lactate-dependent metabolic symbiosis in which lactate produced by the hypoxic, glycolytic NP cells is utilized by the more oxygenated AF cells via oxidative phosphorylation for energy and matrix production, thus shifting the current research paradigm of viewing disc lactate as a waste product to considering it as an important biofuel. These scientifically impactful results suggest novel therapeutic targets in disc metabolism and degeneration.
\end{abstract}

Keywords: Lactate, Lactic acid, Intervertebral disc, Annulus fibrosus, Nucleus pulpous, Glycolysis, Oxidative phosphorylation

\section{Background}

Intervertebral discs (IVDs) are fibrocartilaginous structures necessary for bearing loads and providing flexibility in the spine. Intervertebral disc degeneration (IDD) contributes to several major spine-related pathologies, including chronic low back pain, disability, and debilitating pain that have resulted in tremendous societal health and economic burden exceeding $\$ 100 \mathrm{~B}$ annually in cost [1]. Among the possible drivers of IDD, impaired disc nutrition has long been investigated as a major contributor to the initiation and development of IDD [2].

The IVD is the largest avascular tissue structure comprised of a gelatinous nucleus pulposus (NP) center surrounded by an outer annulus fibrosus (AF). Disc cells receive their nutrients principally through passive diffusion from peripheral capillaries residing in the subchondral plates and outer AF-metabolic wastes are removed by the same mechanism [3]. NP and AF tissue have distinct metabolic and hypoxic environments due to their positions within the IVD. Being farthest from the capillary supply, the NP is hypoxic, while the AF is more oxygenated as it is located closer to the peripheral vasculature [2]. The NP contains the lowest glucose concentration and the highest lactate levels $(5-10 \mathrm{mM})$ because its cells metabolize glucose through anaerobic glycolysis to generate lactic acid which readily dissociates to lactate and $\mathrm{H}+$ due to its low pKa of 3.9. NP produces and secretes an abundant amount of lactate into the extracellular environment [4]. This results in lactate concentration being highest at the disc's center and decreases in concentration going peripherally [5].

Accumulation of lactic acid acidifies the disc microenvironment, which can reduce disc cell viability and function. The $\mathrm{pH}$ range of non-degenerate disc tissue is typically 7.1-7.4. Increased acidity observed in degenerate disc tissue ( $\mathrm{pH}$ 6.2-6.8) has been reported to cause a decrease in cell proliferation and viability, leading to an increase in matrix catabolism and inflammation in human $\mathrm{NP}$ cells [6]. Increased acidity $(\mathrm{pH}<6.8)$ has been shown to dramatically suppress proteoglycan matrix synthesis in human and bovine NP tissue [7]. Acidic $\mathrm{pH}$ has recently been shown to promote cellular senescence in rat NP cell cultures [8], and senescent disc cells exhibit perturbed matrix homeostasis [9]. Hence, perturbation of disc matrix homeostasis by acidic $\mathrm{pH}$ could be mediated through cellular senescence. Based on these observations, the longstanding dogma in the field presumes that lactic acid is a toxic waste product of NP glycolysis that must be removed to maintain disc health $[6,7,10,11]$.

This widespread presumption fails to consider several aspects of disc bioenergetics. First, lactate, is an energy rich metabolite, which can yield $\sim 16$ ATP per lactate molecule if converted to pyruvate and metabolized via oxidative phosphorylation (OXPHOS). Given the inherent nutrient-deprived disc environment, can disc cells afford to waste this energy resource? Second, how do disc cells survive and function in a high lactate milieu in vivo? Herein, we re-examined disc lactate metabolism in light of recent literature from solid tumor research that reported lactate metabolic symbiosis as an alternative metabolic strategy. Solid tumors share similar structural and metabolic features with the disc. The tumor center is hypoxic and glycolytic (structurally analogous to the NP), while the tumor's outer layer is more oxygenated (analogous to the AF). Lactate metabolic symbiosis occurs in solid tumors whereby lactate produced by glycolytic cells from the hypoxic center is utilized through OXPHOS by cells in the more oxygenated outer part of the tumor [12-14]. Although reported relatively recently in solid tumors, the concept of lactate metabolic symbiosis has long been documented in muscle and brain physiology [15-17]. For instance, fast-twitch white muscle fibers have been shown to glycolytically convert glucose to lactate [18] that is then secreted and taken up to be aerobically metabolized by slow-twitch red muscle fibers [19]. Therefore, tissues living in different degrees of hypoxia have evolved to optimize their bioenergetics through lactate symbiosis.

In the present study, we postulate that IVDs employ lactate-dependent metabolic symbiosis as a metabolic adaptation to optimize their cellular bioenergetics, i.e. NP produces lactate via glycolysis and AF consumes lactate via OXPHOS as a biofuel to minimize lactate accumulation and its negative impact on NP cells. We found evidence of robust lactate uptake and OXPHOS by AF cells used to generate energy and amino acids. We also demonstrate that AF cells express the necessary 
molecular machinery for handling lactate, including monocarboxylate transporter 1 (MCT1) for lactate import and lactate dehydrogenase M (LDH-M) for converting lactate into pyruvate for OXPHOS. These new findings are significant in that they support a profound paradigm shift away from seeing lactate as waste in the disc to investigating its role as an alternative carbon source.

\section{Methods}

\section{AF and NP cell cultures}

Twenty-four 7- to 10-week-old female New Zealand White rabbits (Covance, Denver, PA, USA) were used for all experiments. Primary rabbit NP and AF cells were initially expanded on monolayer culture in Gibco Ham's F12 media (11765047, Thermo Fisher Scientific) containing $25 \mathrm{mM}$ glucose and 10\% FBS at 5\% $\mathrm{O}_{2}$. Before being treated with different lactate experimental conditions, passage 1 (P1) cell cultures were conditioned in low glucose DMEM media (5.5 mM glycose, D5921, Sigma) with $4 \mathrm{mM}$ exogenously added sodium lactate (S1324, Spectrum Chemical MFG Corp) to mimic disc physiological nutrient niche for $24 \mathrm{~h}$. Human AF (hAF) cells were isolated from disc surgical specimens (mean $=42$ years, average Thompson degeneration grade 2-3) and cultured in the same manner as rabbit AF cells described above. P1 hAF cells were used to in the ${ }^{13} \mathrm{C}$-lactate tracing assay.

\section{Measurement of cell culture media glucose and lactate} P1 rabbit NP and AF cells were grown on monolayer cultures in Gibco Ham's F12 containing $23 \mathrm{mM}$ glucose and $10 \% \mathrm{FBS}$ at $5 \% \mathrm{O}_{2}$. Glucose and lactate concentrations in the cell culture media were quantified at different time points $(2,6,12,24,48,72 \mathrm{~h})$ using Accutrend Plus System (Roche Diagnostics, Switzerland) for glucose (used $10 \mu \mathrm{l}$ media/time point) and lactate $(0.7 \mu \mathrm{l}$ media/ time point) [20].

\section{CCK8 cell viability assay to assess lactate tolerance by AF cells}

P1 rabbit AF cells cultured in media containing $1.06 \mathrm{mM}$ glucose and 1\% FBS were treated with different sodiumlactate concentrations $(0,2.5,5,7.5,10,20 \mathrm{mM})$ for $48 \mathrm{~h}$ at $5 \% \mathrm{O}_{2}$. Cell viability was measured by CCK-8 assay (CK04, Dojindo Molecular Technologies, Inc., Rockville, MD, USA), following the manufacturer's instructions. Cell morphology and density were also evaluated.

\section{${ }^{14} \mathrm{C}$-lactate uptake assay}

P1 rabbit AF cell culture in a 12-well plate was conditioned for $48 \mathrm{~h}$ in low glucose (5.5 mM glucose) DMEM media, $4 \mathrm{mM}$ lactate, and $10 \% \mathrm{FBS}$ at $5 \% \mathrm{O}_{2}$. AF cells were then pre-treated with an assay media containing
$150 \mathrm{mM} \mathrm{NaCl}, 5 \mathrm{mM} \mathrm{KCl}, 1 \mathrm{mM} \mathrm{MgCl}, 1 \mathrm{mM} \mathrm{CaCl}_{2}$, $25 \mathrm{mM}$ HEPES (pH 7.4), and 0.5\% FBS at $5 \% \mathrm{O}_{2}$ for 30 min. Cells were next labeled for $1 \mathrm{~min}$ in the absence of glucose with different lactate concentrations (1, 2, 4 $\mathrm{mM}$ ) at a constant ${ }^{14} \mathrm{C}$-lactate (NEC599050UC, PerkinElmer) specific activity $(500 \mu \mathrm{Ci} / \mathrm{mmole}$ lactate $)$. Glucose was left out at ${ }^{14} \mathrm{C}$-lactate labeling step because this assay was designed with the sole purpose of initially finding out whether AF cells are capable of importing lactate. The culture media was removed, the cell layer was washed three times with $0.5 \mathrm{ml}$ ice cold assay media, and $0.5 \mathrm{ml}$ of $0.1 \mathrm{M} \mathrm{NaOH}$ was added, followed by $50 \mu \mathrm{l}$ of $0.5 \mathrm{M} \mathrm{HCl}$ to neutralize the solution before cell lysate was collected. $0.4 \mathrm{ml}$ of cell lysate was counted in the Tri-Carb 2100TR Liquid Scintillation Analyzer (Perki$n E l m e r)$. The remaining cell lysate was used to calculate the protein concentration for normalization of cellular ${ }^{14} \mathrm{C}$-lactate uptake. Relative levels of lactate uptake by $\mathrm{AF}$ cells were quantitated using ${ }^{14} \mathrm{C}$ radioactivity from the cell lysate normalized to total protein amount.

\section{${ }^{13} \mathrm{C}$-lactate tracing assay In vitro model}

P1 AF cells were conditioned in low glucose $(5.5 \mathrm{mM})$ DMEM media with $1 \% \mathrm{FBS}$ and $4 \mathrm{mM}$ lactate at $5 \% \mathrm{O}_{2}$ for $24 \mathrm{~h}$ before labeling. For heavy isotope labeling, AF cells were labeled $4 \mathrm{mM} 3{ }^{-13} \mathrm{C}$-lactate (CLM-1578-PK, Cambridge Isotope Laboratories) in media containing 1 $\mathrm{mM}$ or $5 \mathrm{mM}$ glucose and $4 \mathrm{mML}$-glutamine without pyruvate at $1 \%$ or $5 \% \mathrm{O}_{2}$ for $24 \mathrm{~h}$. For controls, cells without heavy isotope labeling $(1 \mathrm{mM}$ glucose, $4 \mathrm{mM}$ lactate) or labeled with $\mathrm{U}_{-}{ }^{13} \mathrm{C}$-glucose (U, uniformly labeled. CLM-1396-PK, Cambridge Isotope Laboratories) in $1 \mathrm{mM}{ }^{13} \mathrm{C}$-glucose and $4 \mathrm{mM}$ lactate) at $5 \% \mathrm{O}_{2}$ for 24 $\mathrm{h}$ were included. Metabolic quenching and extraction of polar metabolite were performed using ice cold $80 \%$ methanol in water with $0.1 \%$ formic acid at a ratio of $500 \mu \mathrm{L}$ per $28.2 \mathrm{~cm}^{2}$ surface area of cell monolayer.

\section{Ex vivo model}

To trace ${ }^{13} \mathrm{C}$ in AF cells within their native extracellular matrix, ex vivo rabbit disc organs containing the superior vertebrae and inferior vertebrae were cultured in low glucose (5.5 mM glucose) DMEM culture media to mimic in vivo circulatory glucose. The disc organs were either cultured in media containing $4 \mathrm{mM}{ }^{13} \mathrm{C}$-lactate or injected with $5 \mu \mathrm{l}$ of $40 \mathrm{mM}{ }^{13} \mathrm{C}$-lactate into the NP region using the Hamilton syringe with a 25 -gauge needle. The un-injected and injected disc organs were cultured for 3 days to allow permeation of ${ }^{13} \mathrm{C}$-lactate into the $\mathrm{AF}$ tissue. AF tissues were dissected and snap frozen before being analyzed by high resolution mass spectrometry (HRMS). 


\section{In vivo model}

To trace ${ }^{13} \mathrm{C}$ in AF cells in vivo, two caudal discs (C7C8, C8-C9) in the tails of anesthetized Fischer 344 rats ( $n=3$, 4-month-old male rats) were injected with $1 \mu \mathrm{l}$ of $100 \mathrm{mM}{ }^{13} \mathrm{C}$-lactate into the NP region using the airtight Hamilton syringe (\#80266 Model 1702 LT Threaded Plunger SYR, Hamilton, MA, USA) and 25-gauge needle (\#7750-16 Kel-F Hub Needle, Hamilton, MA, USA). The injection was estimated to give about $5-10 \mathrm{mM}{ }^{13} \mathrm{C}$-lactate final concentration in the entire disc volume. The rats were sacrificed 3 days post-injection, and AF tissue from the injected and un-injected disc control (C6-C7, C9-C10) was harvested separately from NP tissue under a dissecting microscope and snap frozen. The frozen tissue was homogenized in ice cold $80 \%$ methanol in water with $0.1 \%$ formic acid at a ratio of $15 \mu \mathrm{L}$ per $\mathrm{mg}$, at $60 \mathrm{hz}$ for $1 \mathrm{~min}$ in a FastPrep homogenizer with matrix A garnet and ceramic matrix (MP Biomedical, Irvine, $\mathrm{CA}$ ) before being processed by HRMS as described below.

\section{Sample preparation for HRMS}

D4-taurine, D3-alanine, D3-lactate, and D3-creatinine (Sigma-Aldrich) were added to the cell or tissue lysates as an internal standard for a final concentration of $100 \mu \mathrm{M}$. The supernatant fluid of the cell or tissue lysate was cleared of protein by centrifugation at $16,000 \times g$. Samples $(2 \mu \mathrm{L})$ were subjected to online LC-HRMS analysis.

\section{LC-HRMS method}

Samples were analyzed by untargeted LC-HRMS (University of Pittsburgh Health Sciences Metabolomics and Lipidomics Core). Samples were injected via a Thermo Vanquish UHPLC and separated over a reversed phase Thermo Hypercarb porous graphitic column $(2.1 \times 100$ $\mathrm{mm}, 3.0 \mu \mathrm{m}$ particle size) maintained at $50^{\circ} \mathrm{C}$. For the 20 -min LC gradient, the mobile phase consisted of the following: solvent A ( $0.1 \%$ formic acid in water $)$ and solvent $\mathrm{B}(0.1 \%$ formic acid in acetonitrile). The gradient was as follows: $0-12.0 \mathrm{~min} 5 \% \mathrm{~B}$, to $1000 \% \mathrm{~B} ; 12.0-15.0$ min held at $100 \%$ B, $15.0-15.1100 \%$ to $5 \%$ B; $15.1-20.0$ $\min 5 \%$ B. Spectra was acquired on a Thermo IDX tribrid mass spectrometer, using both positive and negative ion mode, scanning in Full MS mode (2 $\mu$ scans) from 70 to $800 \mathrm{~m} / \mathrm{z}$ at 120,000 resolution with an AGC target of $5 \mathrm{e} 4$. Source ionization settings was $3.5 / 2.6 \mathrm{kV}$ spray voltage respectively for positive and negative mode. Source gas parameters was 20 sheath gas, 10 auxiliary gas at $300^{\circ} \mathrm{C}$, and 4 sweep gas. The calibration was performed prior to analysis using the Pierce Positive and Negative Ion Calibration Solutions (Thermo Fisher Scientific). Integrated peak areas were then extracted manually using Quan Browser (Thermo Fisher Xcalibur ver. 2.7). ${ }^{13} \mathrm{C}$ enrichment and natural abundance corrections were calculated using previously established MIMOSA methodology [21]. Graphs and statistical analyses (either $t$ test or ANOVA) were prepared with GraphPad Prism 7.0 (GraphPad Software, Inc., La Jolla, CA, USA). We measured enrichment or atoms percent excess (APE) for lactate, pyruvate, acetyl-CoA, citrate, succinate, and malate as well as the amino acids glutamate, glutamine, and valine.

\section{Western blots}

AF and NP tissues were carefully isolated separately from lumbar discs of four 6-month-old female New Zealand White rabbits. Tissue protein extracts were prepared using T-PER Tissue Protein Extraction Reagent with proteinase inhibitor cocktail as per the manufacturer's instructions (Cat. No 78510, Thermo Fisher). Western blots were performed as described previously [22] to detect hexokinase-1 (Anti-HK, Ab150423, Abcam), MCT4 (anti-MCT4, SC-376140, Santa Cruz Biotechnolgy), LDHA (anti-LDHA, PA5-27406, Invitrogen), MCT1 (anti-MCT1, AB93048, Abcam), LDHB (anti-LDHB, Ab85319, Abcam), and pyruvate dehydrogenase (PDH; anti-PDH, \#2784S, Cell Signaling Technology). Loading control $\beta$-actin (Cat. No. PA1-183, Thermo Fisher) and anti-rabbit HRP secondary antibody (Cat. No. 31460, Thermo Fisher) were used.

\section{Bioenergetic flux measurement by Seahorse XFe96}

Four independent P1 AF cells from four rabbits were cultured in low-glucose DMEM containing 5.5-mM glucose and $10 \%$ FBS at $5 \% \mathrm{O}_{2}$ in $\pm 4 \mathrm{mM}$ lactate. AF cell bioenergetic flux in the presence and absence of lactate was measured by using Seahorse XFe96 Analyzer as previously described [23]. Oxygen consumption rate (OCR) was calculated and normalized to protein amount as measured using the Crystal Violet dye (C3886, Sigma-Aldrich). Individual parameters of OXPHOS were derived from OCR profiles, including mitochondrial respirationmediated ATP production, as described [23, 24].

\section{Matrix protein synthesis by AF cells}

Four independent P1 AF cells from four rabbits were cultured in $\pm 4 \mathrm{mM}$ lactate in 1 or $5 \mathrm{mM}$ glucose at $5 \%$ $\mathrm{O}_{2}$ for 3 days in $0.5 \mathrm{ml}$ of F-12/DMEM containing 10\% FBS, $1 \%$ PS, and $25 \mu \mathrm{g} / \mathrm{ml} \mathrm{L-ascorbic} \mathrm{acid} \mathrm{in} \mathrm{a} 48$-well plate in the presence of $20 \mu \mathrm{Ci} / \mathrm{ml}{ }^{35} \mathrm{~S}$-sulfate (to measure proteoglycan synthesis) and $10 \mu \mathrm{Ci} / \mathrm{ml}$ collagenasesensitive ${ }^{3} \mathrm{H}$-proline (to measure collagen synthesis) at $37^{\circ} \mathrm{C}$. Assays of proteoglycan and collagen syntheses by AF cells were performed as previously described [25]. The rate of synthesis was calculated as fmoles of proline (collagen synthesis) or sulfate (proteoglycan synthesis) incorporated per $\mu \mathrm{g}$ DNA as measured using the 
QuantiT $^{\mathrm{Tu}}$ PicoGreen $^{\mathrm{Tm}}$ dsDNA Assay Kit (P7589, Life Technologies).

\section{Results}

\section{Rationale}

This study is motivated by our new hypothesis postulating that lactate produced by NP glycolysis is not a waste end-product in the IVD but rather is an important and precious carbon source for OXPHOS in AF cells residing in a nutrient-poor but more oxygenated disc environment. We also hypothesize that utilization of lactate by AF cells also serves to minimize NP lactate accumulation and its negative impact on NP cells. To investigate our postulated lactate-dependent metabolic symbiosis between NP and AF, we examined the capacity of AF cells to uptake and utilize lactate using in vitro AF cell and ex vivo disc organ culture model systems. Both radioactive and stable isotope tracing by HRMS were employed for this purpose. Rabbit models were used as they provide enough disc cells for cell cultures, and their disc size is sufficiently large for the ${ }^{13} \mathrm{C}$-lactate injection and tracing study. Additionally, we decided to perform initial characterization of lactate metabolic symbiosis in young normal discs, which are readily available in rabbits but not in humans.

\section{AF cells are less glycolytic than NP cells}

Because we used rabbit nucleus pulposus (rNP) and annulus fibrosus (rAF) cell cultures as the model system in our study, we first needed to confirm that these cell types in our in vitro model exhibit metabolic features consistent with those previously reported [23, 26]. Indeed, rNP cells grown in culture at $5 \% \mathrm{O}_{2}$ readily consumed glucose (Fig. 1a) and then produced and secreted lactate at a high steady-state rate (Fig. 1b). In contrast, AF cells grown under the same condition produced a much lower amount of lactate (Fig. 1d), but also consumed glucose at a much slower rate than NP cells (Fig. 1c) even though AF cells proliferate at similar or faster rates than NP cells under these conditions $[23,27,28]$. These results suggest that AF cells are less glycolytic than NP cells and that AF cells use less glucose than NP cells, likely because AF cells utilize OXHPOS which generates more ATP per glucose than glycolysis.

\section{AF cells tolerate high lactate levels}

In anaerobic NP tissue, pyruvate generated from glycolysis is converted to lactic acid. Given its low pKa of 3.9, lactic acid readily dissociates into lactate and $\mathrm{H}+$ which acidifies the disc tissue. It is the acidity created by lactic acid, not lactate, that is reported to cause harm to cells. Physiological lactate concentrations in human disc tissue from periphery to the center have been reported to range from 2 to $16 \mathrm{mM}$ while glucose concentrations range from 1 to $5 \mathrm{mM}$ [4]. To determine if rAF cells in culture could tolerate lactate in this physiologic range, rAF cell cultures were exposed to media containing exogenously added lactate ranging from 0 to $20 \mathrm{mM}$
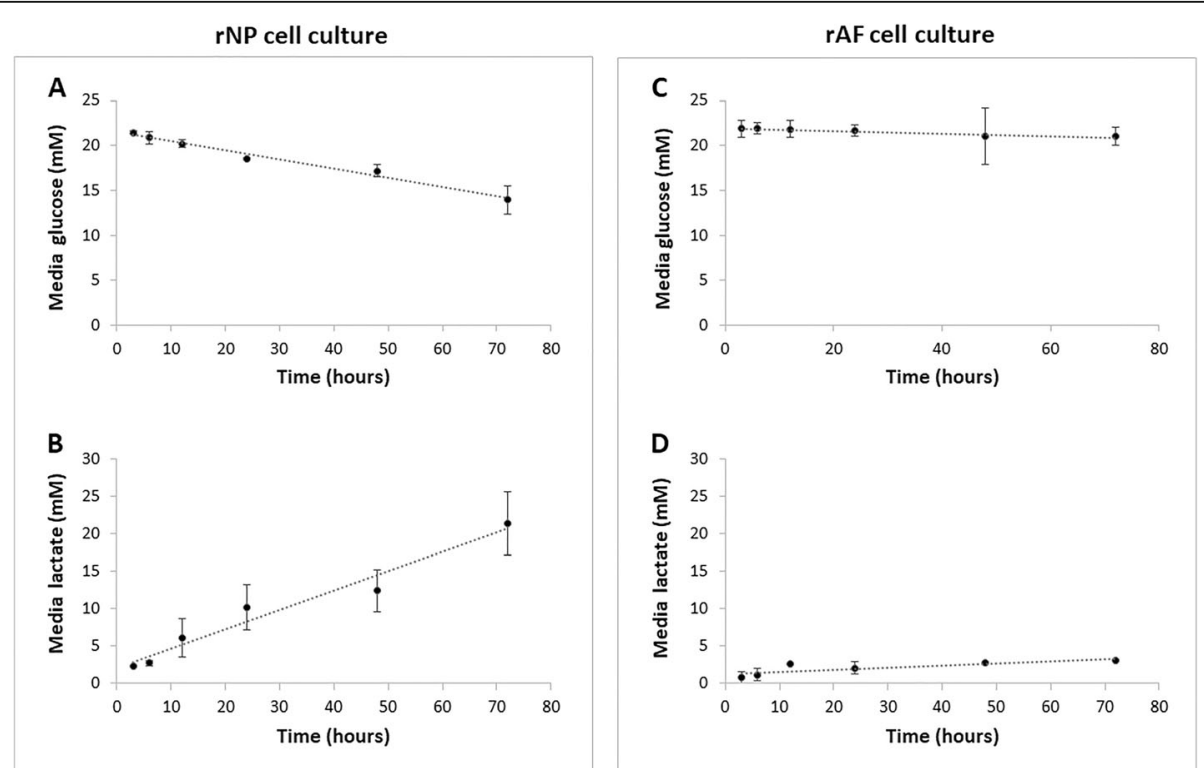

Fig. 1 Distinct metabolic features of NP and AF cells in cell culture. Rabbit NP and AF cells were grown on monolayer cultures in Gibco Ham's F12 media at $5 \% \mathrm{O}_{2}$, and the concentrations of glucose and lactate in their culture media were measured by Accutrend Strips at different time points. NP cells in cell culture are highly glycolytic that readily consumed glucose (a) and produced and secreted an abundance of amount of lactate (b) in a time-dependent manner. Under the same culture condition, AF cells both consumed glucose (c) and produced lactate (d) at much slower rates compared to NP cells, suggesting that AF cells are less glycolytic and more aerobic in their metabolism 
lactate in the presence of physiologic glucose concentration $(1.06 \mathrm{mM})$. Lactate up to $10 \mathrm{mM}$ had no effects on AF cell viability in culture as assessed by CCK8 assay (Figure S1. B, Supplementary Material). Only at high lactate $(20 \mathrm{mM})$ concentration did we observed a modest decrease in AF cell viability by about $20 \%$. Lactate up to $10 \mathrm{mM}$ also had no discernable effects on AF cell morphology or density in vitro (Figure S1. A, Supplementary Material). Given that normal blood lactate concentration is $0.5-1 \mathrm{mM}$, these results suggest that $\mathrm{AF}$ cells have evolved to tolerate high lactate concentrations in disc tissue that are 5-10 times the level found in serum [5]. Because AF physiologic lactate concentrations range mostly between 2 and $6 \mathrm{mM}$ [4], we chose $4 \mathrm{mM}$ lactate to test its effects on AF cell metabolism in all our subsequent experiments.

\section{Lactate uptake by AF cells}

To determine whether AF cells can import lactate from their extracellular environment, we performed a radioactive tracing assay using ${ }^{14} \mathrm{C}$-lactate to measure cellular ${ }^{14} \mathrm{C}$ uptake. Rabbit AF cells exposed to increasing ${ }^{14} \mathrm{C}$-lactate concentrations resulted in a proportional increase in ${ }^{14} \mathrm{C}$ levels in the cells after the cells were extensively washed with PBS to remove nonspecific binding of ${ }^{14} \mathrm{C}$ lactate (Fig. 2a). To be sure that uptake was not due to nonspecific attachment of ${ }^{14} \mathrm{C}$-lactate to cells or plastic surface of the culture plate, we also included no-cell and dead cell controls, e.g. AF cells killed with $40 \%$ ethanol. These control samples showed minimal radioactive counts (Fig. 2a), suggesting negligible nonspecific binding of ${ }^{14} \mathrm{C}$ lactate to AF cells. HepG2 cells, a human hepatocyte carcinoma cell line known to import lactate, were also included as a positive control for our uptake assay which resulted in a ${ }^{14} \mathrm{C}$-lactate-concentration dependent increase in radioactive counts in the cell lysate, as expected (Figure S2, Supplementary Material). The results from our ${ }^{14} \mathrm{C}$-lactate uptake assay demonstrated lactate import into AF cells.

Lactate import into cells is mediated preferentially via the monocarboxylate transporter 1 (MCT1) [29, 30]. To determine if AF cells express MCT1, we performed qRT-PCR and found higher MCT1 mRNA expression in AF cells cultured in the presence of lactate (Fig. 2b). Additionally, AF but not NP tissue expresses an abundant amount of MCT1 protein (Fig. 2c). Our findings suggest that AF has the molecular machinery and capability to import lactate from the extracellular environment. In contrast, MCT4 protein, a known lactate exporter in hypoxic tissue [12, 31, 32], is expressed mostly in NP but not AF tissue (Fig. 2c). These data support the notion of lactate metabolic synergy between NP and AF tissues whereby NP produces and exports lactate via MCT4 into the extracellular space, which is then imported into AF cells via MCT1.

\section{Lactate conversion to pyruvate by AF cells}

Because AF cells reside within a more oxygenated region of the disc, we postulate that AF cells convert lactate

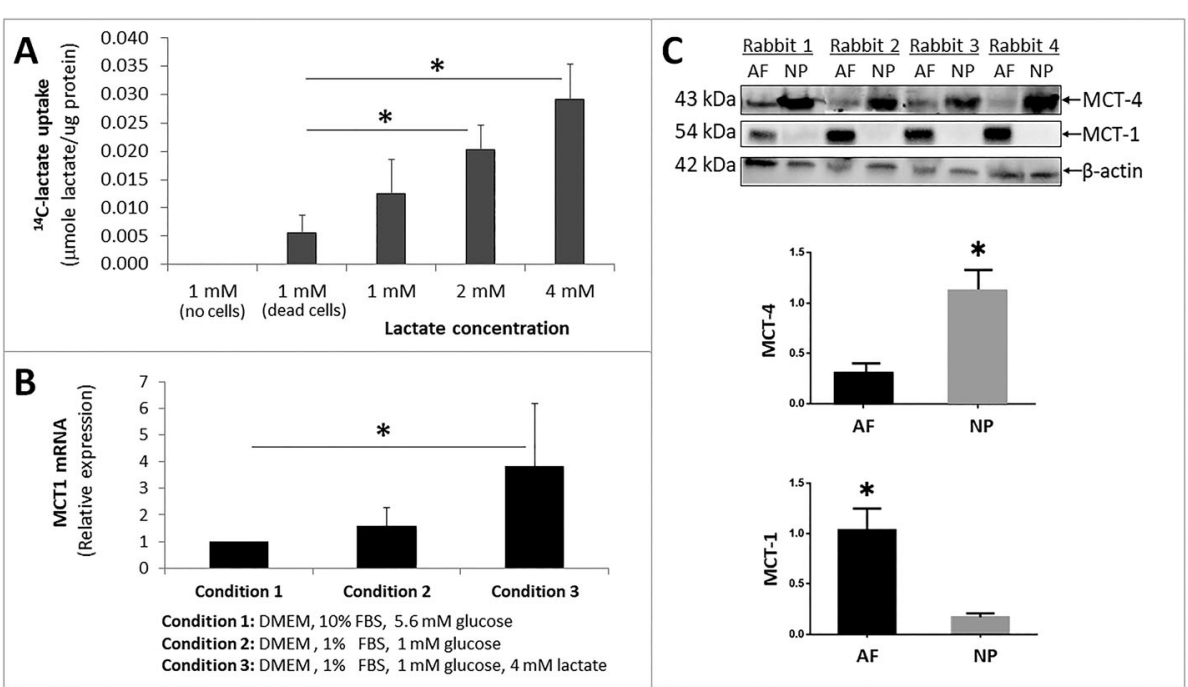

Fig. 2 Lactate import into AF cells. $\mathbf{a},{ }^{14} \mathrm{C}$-lactate radioactive tracing to assess lactate import into AF cells. Rabbit AF cell cultures were grown in 1 $\mathrm{mM}$ glucose and varying concentrations of ${ }^{14} \mathrm{C}$-lactate (1-4 mM) for $1 \mathrm{~min}$, washed with PBS, lysed, and counted in scintillation fluid. $\mathbf{b}$, Lactate enhances MCT1 mRNA expression in AF cells. Rabbit AF cells were cultured under three different conditions, and their MCT1 mRNA levels were measured by qRT-PCR. c, Western blot of MCT-1 and MCT-4 in rabbit AF and NP tissue protein extract (top) and quantification of MCT-1 and MCT-4 expression levels by normalizing to $\beta$-actin as loading control (bottom). Data are means \pm SEM of four independent experiments (4 rabbits). ${ }^{*} p<0.05$ 
back into pyruvate for its subsequent conversion to acetyl-coA to be shuttled in the TCA cycle for OXPHOS. To test this idea, we performed stable isotope tracing using $3-{ }^{13} \mathrm{C}$-lactate by HRMS. AF cell cultures labeled with $4 \mathrm{mM} 3-{ }^{13} \mathrm{C}$-lactate for $24 \mathrm{~h}$ resulted in $35 \pm 4 \%$ atomic percent enrichment (APE) of $\mathrm{M}+1$ lactate and $19 \pm 6 \%$ APE of $M+1$ pyruvate (Fig. 3a). $M+1$ indicates that one ${ }^{13} \mathrm{C}$ carbon is present in these molecules. These findings confirmed that lactate is taken up and converted into pyruvate by AF cells in an in vitro cell culture model system.

To further demonstrate that AF cells in their native tissue are also capable of importing lactate and converting it to pyruvate, we performed stable isotope ${ }^{13} \mathrm{C}$-lactate labeling using an ex vivo disc organ culture model. Rabbit functional spine units (FSUs) containing vertebrae-disc-vertebrae were injected with $3{ }^{-13} \mathrm{C}$-lactate into the NP region to give an estimated final $3{ }^{13} \mathrm{C}$-lactate concentration of $\sim 5-10 \mathrm{mM}$. The FSUs were then incubated in the culture media for 3 days before being analyzed by HRMS. Under these conditions, there was a $28 \pm 15 \%$ enrichment in $\mathrm{M}+1{ }^{13} \mathrm{C}$-lactate and $19 \pm 9 \%$ APE in $M+1$ pyruvate in AF tissue (Fig. 3b). As a control, we also incubated rabbit FSUs in culture media containing $4 \mathrm{mM} 3-{ }^{13} \mathrm{C}$-lactate for 3 days which resulted in $68 \pm 9 \%$ enrichment in $\mathrm{M}+1{ }^{13} \mathrm{C}$-lactate and $48 \pm 7 \%$ APE in $M+1$ pyruvate in AF tissue extract (Figure S3, Supplementary Material). These findings demonstrated that AF cells in their native tissue environment can uptake and convert lactate into pyruvate.

Lactate dehydrogenase isozyme 1 (LDH1), a homotetramer of four $\mathrm{H}$ protein subunits, preferentially converts lactate to pyruvate (Fig. 3c) [33, 34]. $\mathrm{H}$ is expressed significantly more in AF than NP tissue as shown by Western blot analysis (Fig. 3e), which is consistent with ${ }^{13} \mathrm{C}$ being traced to pyruvate in our ${ }^{13} \mathrm{C}$-lactate tracing experiment. However, the presence of $\mathrm{H}$ protein in NP tissue suggests that NP cells also are enzymatically
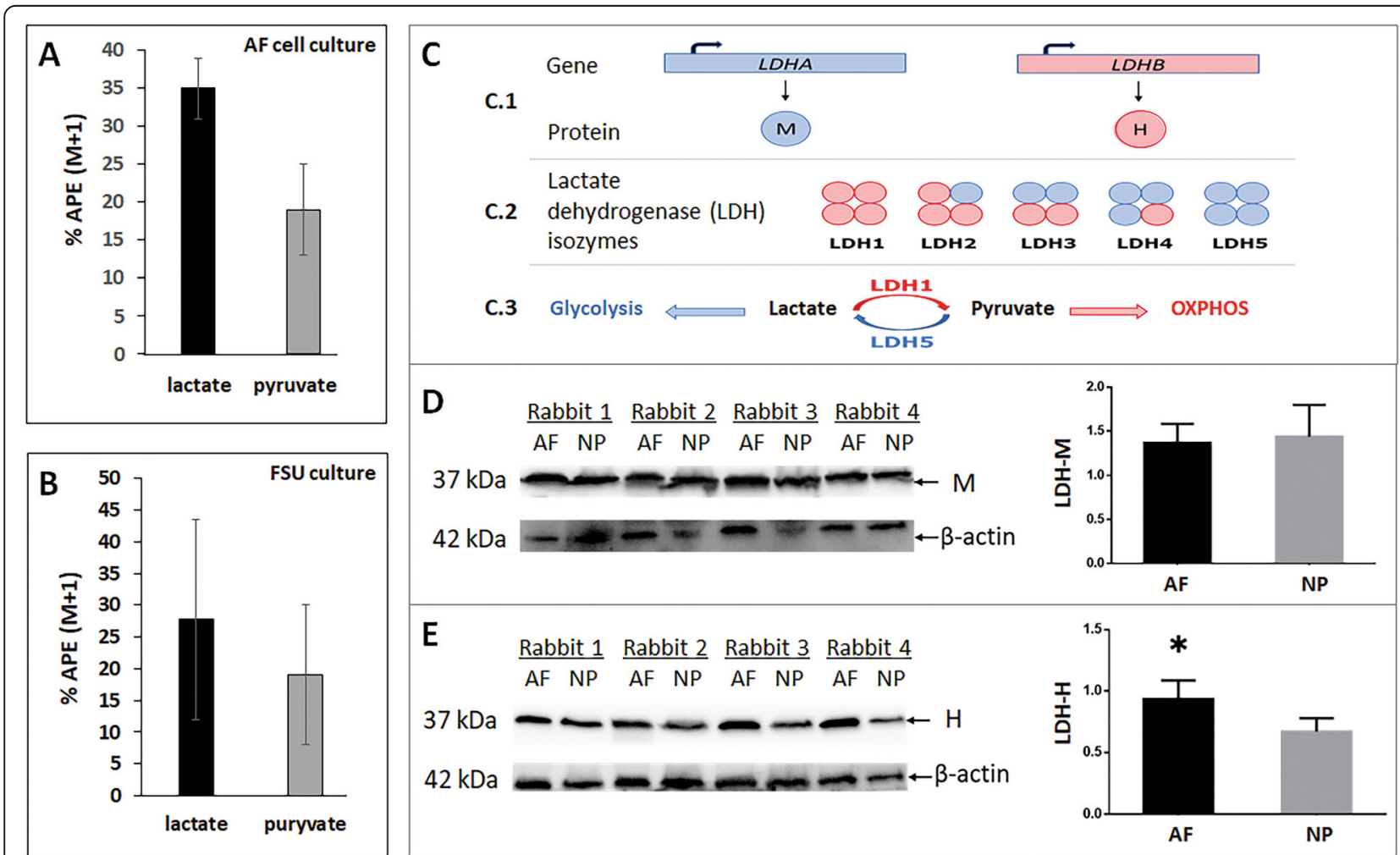

Fig. 3 Lactate conversion to pyruvate in AF cells. ${ }^{13} \mathrm{C}$-lactate tracing to pyruvate in rabbit AF cells in cell culture containing $4 \mathrm{mM} 3-{ }^{13} \mathrm{C}$-lactate $(\mathbf{a})$ and in AF tissue extract derived from the rabbit functional spine unit (FSU) culture 3 days post injection of $5 \mu$ l of $40 \mathrm{mM}{ }^{13} \mathrm{C}$-lactate into the NP region of the disc (b). Intracellular enrichment of ${ }^{13} \mathrm{C}$ lactate or ${ }^{13} \mathrm{C}$ pyruvate AF cells from AF cell culture or AF tissue of the ex vivo disc organ culture is reported as atomic percent excess (APE) of the total amount of lactate or pyruvate, e.g., 10\% APE of pyruvate indicates $10 \%$ of total pyruvate contains ${ }^{13} \mathrm{C}$. Percent (\%) APE shown $(\mathrm{M}+1)$ indicates that one ${ }^{13} \mathrm{C}$ carbon is present. c, Schematic of gene expression and assembly of lactate dehydrogenase (LDH), the primary enzyme that catalyzes the interconversion of lactate and pyruvate. LDH exists in five isozymes composed of a tetramer of $\mathrm{M}$ and $\mathrm{H}$ protein subunits encoded by the LDHA and LDHB genes, respectively. LDH5, composed of four M subunits, preferentially converts pyruvate to lactate while LDH1, consisting of four $\mathrm{H}$ subunits, preferentially converts lactate to pyruvate. Western blot of $\mathrm{LDHM}(\mathbf{d})$ and LDHH (e) in rabbit AF and NP tissue protein extract and their protein levels were quantified by normalizing to $\beta$-actin as loading control (graphs). Data are means \pm SD of four independent experiments (four rabbits). ${ }^{*} p<0.05$ 
capable of converting lactate to pyruvate to a certain extent. LDH5, an isozyme consisting of a homo-tetramer of four $\mathrm{M}$ protein subunits, preferentially converts pyruvate to lactate [33, 34]. We expected the $M$ protein to be expressed mostly in the hypoxic NP and less so in AF tissue. Surprisingly, this was not the case as $M$ is expressed similarly in both NP and AF tissue (Fig. 3d), suggesting that AF cells possess as as much enzymatic capability as NP cells to convert pyruvate to lactate.

Although pyruvate can enter the triccyclic acidic (TCA) cycle through its conversion to oxoaloacetate by pyruvate carboxylase, pyruvate primarily enters the TCA cycle through its conversion to acetyl-coA (Fig. 6). The enzyme responsible for catalyzing the conversion of pyruvate to acetyl-coA is pyruvate dehydrogenase (PDH). As expected, PDH is expressed three fold more in AF than NP tissue (Fig. 4A). Conversely, pyruvate dehydrogenase kinase 1 (PDK1), an enzyme that phosphorylates and inhibits PDH activity, is expressed about twofold more in NP than AF tissue (Fig. 4A). Together, these results are consistent in indicating that $\mathrm{AF}$ cells, much more so than NP cells in disc tissue, possess the molecular machinery necessary for importing lactate through MCT1, converting lactate to pyruvate by LDH1, and converting pyruvate to acetyl-coA by PDH.

\section{Lactate conversion to TCA intermediates and amino acids} by AF cells

Our ${ }^{13} \mathrm{C}$-lactate tracing experiment using a rabbit $\mathrm{AF}$ cell culture model also revealed that ${ }^{13} \mathrm{C}$ was present in several tricarboxylic acid (TCA) intermediates, including $\alpha$-ketoglutarate, succinate, fumarate, and malate at 615\% APE range (Fig. 4B). In addition, intracellular enrichment of ${ }^{13} \mathrm{C}$ on these four TCA intermediates in $\mathrm{AF}$ cells was negligibly affected by $1 \mathrm{mM}$ vs. $5 \mathrm{mM}$ glucose or $2 \%$ vs. $5 \%$ oxygen. Detection of ${ }^{13} \mathrm{C}$ label in these

\section{A. Expression of PDH and PDK}

\section{A.1}

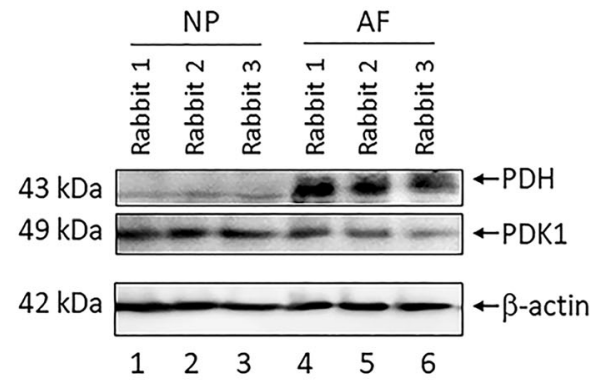

A.2

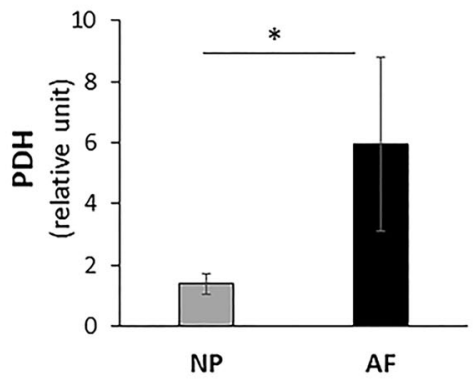

A.3

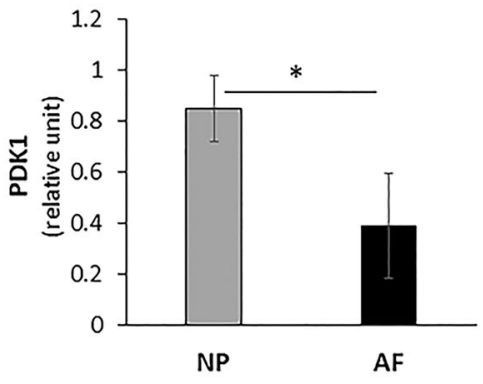

\section{B. Tracing of ${ }^{13} \mathrm{C}$ from ${ }^{13} \mathrm{C}$-lactate to TCA intermediates}
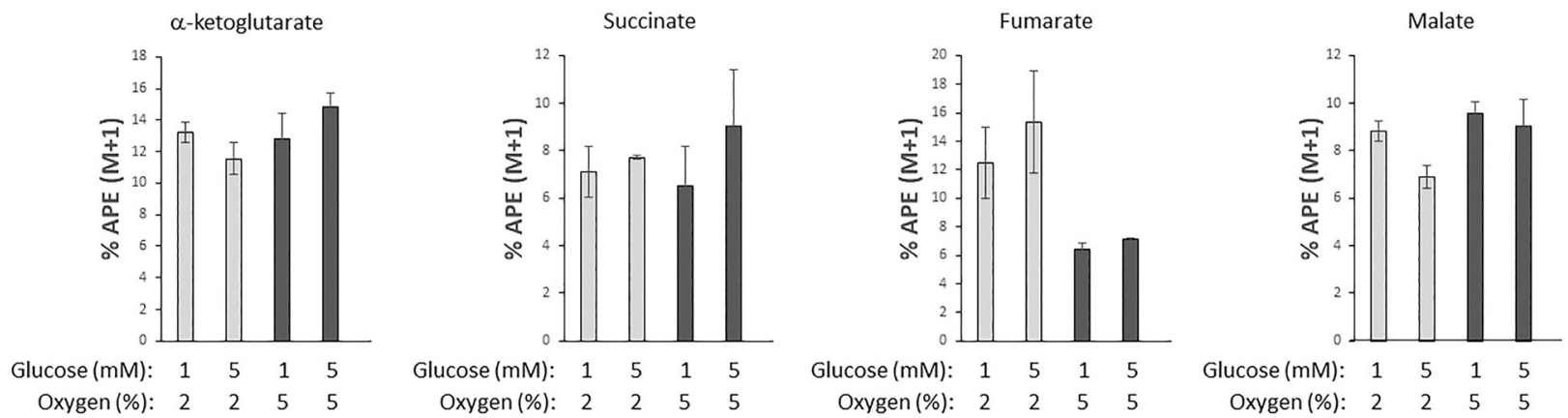

Fig. 4 Lactate uptake and conversion to TCA intermediates and amino acids in AF cells. A PDH and PDK1 protein expression in AF and NP tissues. Western blot of PDH and PDK1 in rabbit AF and NP tissue protein extract (A.1), and PDH (A.2) and PDK1 (A.3) protein levels were quantified by normalizing to $\beta$-actin as loading control (graphs). Data are means \pm SD of three independent experiments (three rabbits). ${ }^{*} p<$ 0.05. B ${ }^{13} \mathrm{C}$ from ${ }^{13} \mathrm{C}$-Lactate was traced to TCA intermediates and amino acids in AF cells. Rabbit AF cell cultures grown in $2 \%$ or $5 \% \mathrm{O}_{2}$ were labeled with the stable isotope $3{ }^{-13} \mathrm{C}$-lactate $(4 \mathrm{mM})$ in the presence of $1 \mathrm{mM}$ or $5 \mathrm{mM}$ glucose; ${ }^{13} \mathrm{C}$ was traced to different TCA intermediates by HRMS. Intracellular enrichment of ${ }^{13} \mathrm{C}$ on different metabolites in AF cells was measured in APE or atom percent excess. Data are means \pm SEM of four independent experiments (four rabbits) 
TCA metabolites, with $\alpha$-ketoglutarate, succinate and fumarate being the precursors of malate, might be due to the unfavorable thermodynamic reaction of converting malate to oxaloacetate by malate dehydrogenase $(\Delta \mathrm{G}=+$ $6.7 \mathrm{kcal} \mathrm{mol}^{-}$) [35], resulting in the buildup of these TCA intermediates (Fig. 6). The presence of lactatehandling enzymes combined with the observed production of TCA cycle intermediates from lactate in AF cells provide strong support that these cells are capable of importing and aerobically metabolizing lactate as a carbon source.

In addition to detecting heavy isotope labeling in the TCA intermediates, ${ }^{13} \mathrm{C}$ was also traced to several amino acids in AF cell culture labeled with ${ }^{13} \mathrm{C}$-lactate. These include $\mathrm{M}+1$ glutamate ( $31 \pm 5 \% \mathrm{APE}), \mathrm{M}+1$ glutamine $(0.5 \pm 0.2 \% \mathrm{APE})$, and $\mathrm{M}+1$ alanine $(4.2 \pm 0.2 \mathrm{APE})$ (Figure S4A, Supplementary Material). These results suggest that AF cells can utilize lactate to make amino acids since alanine biosynthesis can be derived from pyruvate and both glutamine and glutamate can be enzymatically derived from $\alpha$-ketoglutarate [36] (Fig. 6).

Using the same ${ }^{13} \mathrm{C}$-lactate tracing experiment, we also traced ${ }^{13} \mathrm{C}$ to the malate and glutamate in human AF cell culture (Figure S4C, Supplementary Material), and more importantly in rat AF tissues in vivo (Figure S4D, Supplementary Material) to approximately $10 \%$ APE. Together, these findings demonstrated that AF cells, in both in vitro cell culture and in vivo models, can uptake and convert lactate to TCA intermediates and amino acids, and that this metabolic phenotype appears to be universal, i.e. not species specific.

\section{Lactate oxidative phosphorylation by AF cells}

Conversion of lactate into TCA intermediates by AF cells implies oxidative phosphorylation (OXPHOS) of lactate. However, ${ }^{13} \mathrm{C}$ from ${ }^{13} \mathrm{C}$-lactate was also traced to amino acids, suggesting that lactate is used by AF cells for biosynthesis in addition to being used in OXPHOS to generate ATPs. To determine directly if lactate is used for OXPHOS, rabbit AF cells cultured in $1 \mathrm{mM}$ glucose $\pm 4 \mathrm{mM}$ lactate were analyzed using the Seahorse XFe96 Extracellular Flux Analyzer. Oxygen consumption rate (OCR), which reflects the extent of OXPHOS, was measured at basal conditions and following addition of specific inhibitors of the electron transport chain (Figure S5A, Supplementary Material) [37]. Under these conditions, lactate increased the basal OCR rate and the mitochondrial ATP-linked respiration in AF cells (Fig. 5A), but it did not have any significant effects on several individual parameters of OXPHOS, including reserve capacity, maximum total respiratory capacity, proton leak, non-glucose respiration, and nonmitochondrial oxygen consumption (Figure S5B, Supplementary Material).
These findings provide further evidence of lactate metabolism via OXPHOS to generate ATP in AF cells.

\section{Lactate increases matrix synthesis in AF cells}

Lactate increases OXPHOS and mitochondrial ATPlinked respiration, as well as production of amino acids in AF cells when they were grown under the physiological nutrient condition of low glucose $(1 \mathrm{mM})$. A vital function of AF cells is to synthesize extracellular matrix, particularly the collagens, a process requires energy and amino acid building blocks. These observations raised a question of whether lactate can serve as a biofuel for matrix synthesis in AF cells. Indeed, our matrix synthesis assays using radioactive tracers revealed that AF cells synthesized almost twice as much as the total collagen (Fig. 5B, panel B.2) in the presence of $4 \mathrm{mM}$ lactate than without when cells were grown in low glucose $(1 \mathrm{mM})$ that mimic disc nutrient niche. Likewise, lactate stimulated total protein synthesis in AF cells to about 20\% under the same condition (Fig. 5B, panel B.1). Interestingly, proteoglycan synthesis was also slightly increased in the presence of lactate but was not statistically significant (Fig. 5B, panel B.3). In addition, AF cells cultured in $5 \mathrm{mM}$ lactate produced collagen and total proteins to a comparable level to that found in AF cells cultured in 5 $\mathrm{mM}$ glucose; and AF cells cultured in $1 \mathrm{mM}$ glucose and $4 \mathrm{mM}$ lactate, which add up to a total of $5 \mathrm{mM}$ between these two carbon sources, exhibited a slight but statistically nonsignificant decrease in collagen and total protein synthesis compared to AF cells grown in $5 \mathrm{mM}$ lactate or $5 \mathrm{mM}$ glucose (Figure S6D, Supplementary Material). Together, these findings demonstrate that under physiologic glucose concentration AF cells utilize lactate nearly as efficiently as glucose as a biofuel to produce matrix protein. In contrast, lactate treatment of NP cell cultures decreased overall matrix synthesis in these cells, albeit statistically nonsignificant, suggesting that NP cells do not metabolize lactate to make matrix (Figure S6, panels A-C in Supplementary Material).

\section{Discussion}

Hypoxic NP cells produce and secrete large quantities of lactic acid into the extracellular environment of IVDs. Lactic acid acidifies tissue and NP cells have recently been shown in mice to adapt to acidic $\mathrm{pH}$ through the action of the proton/lactate exchange pump MCT4 to maintain intracellular $\mathrm{pH}$ [38]. The mechanism by which AF cells adapt in order to function in high lactic acid milieu and the associated acidity in disc tissue is largely unknown [39]. Until now, it has been commonly believed that disc tissue excretes lactate as an end waste product to prevent cytotoxic buildup. Here, we provided clear evidence through in vitro and in vivo experiments demonstrating that lactate can be imported into AF cells 

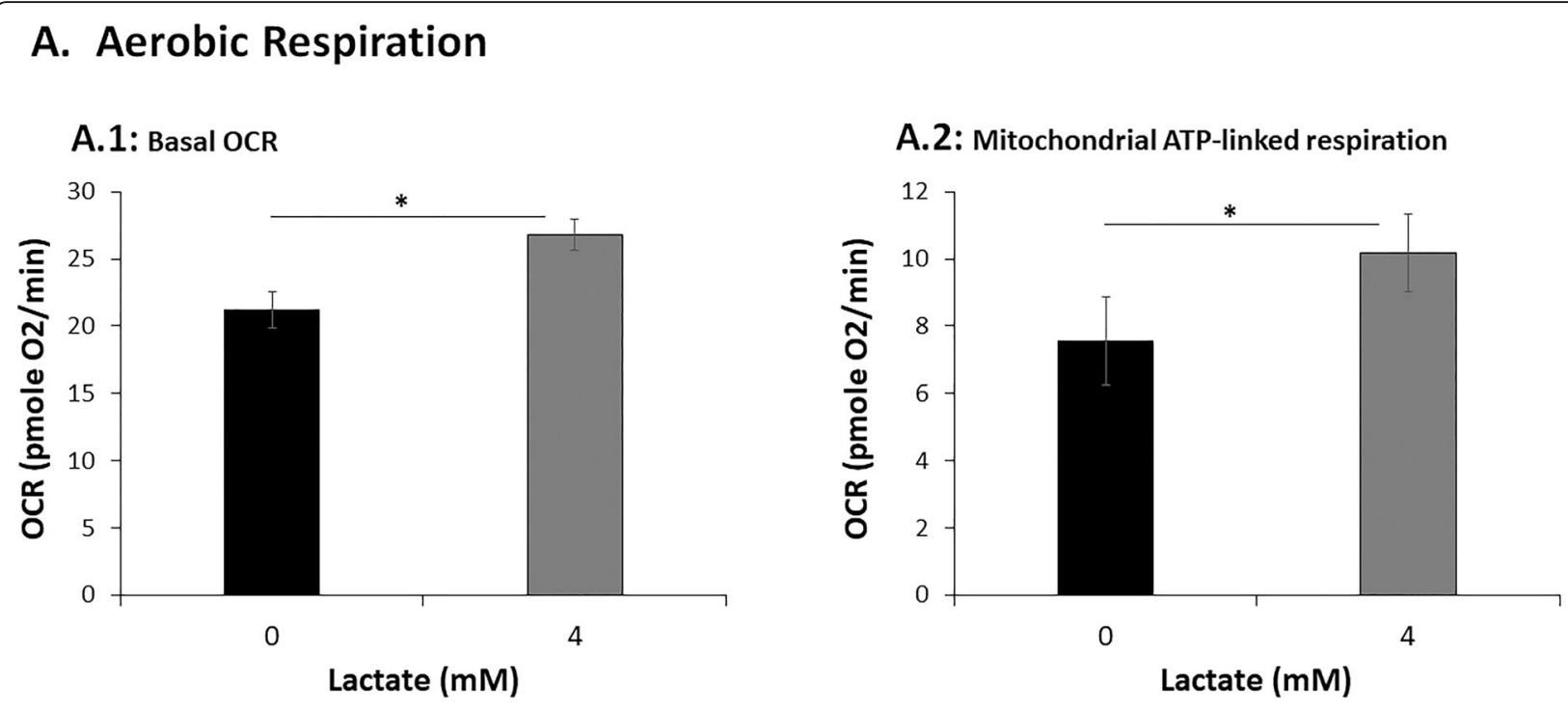

\section{B. Matrix Synthesis}

\section{B.1: Protein Synthesis}

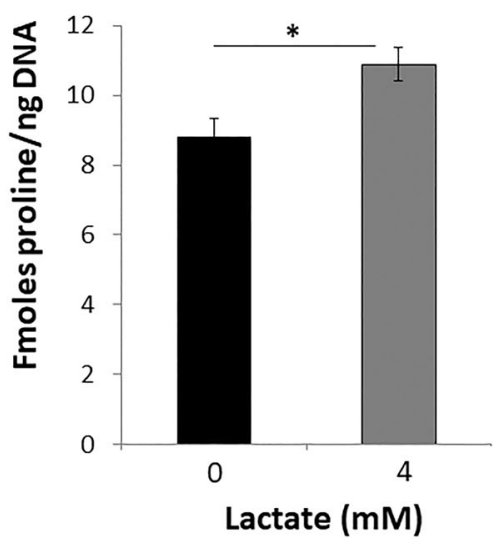

B.2: Collagen Synthesis

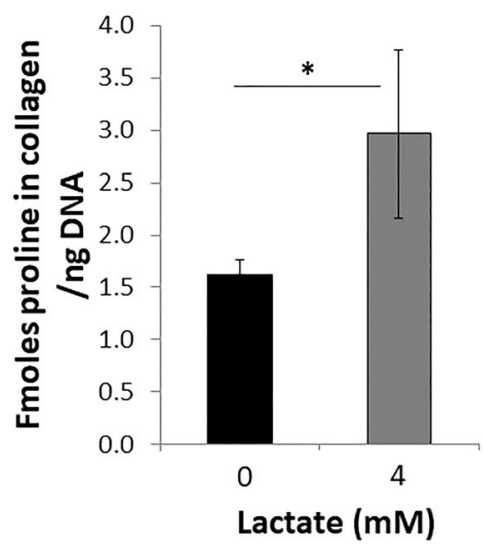

B.3: Proteoglycan Synthesis

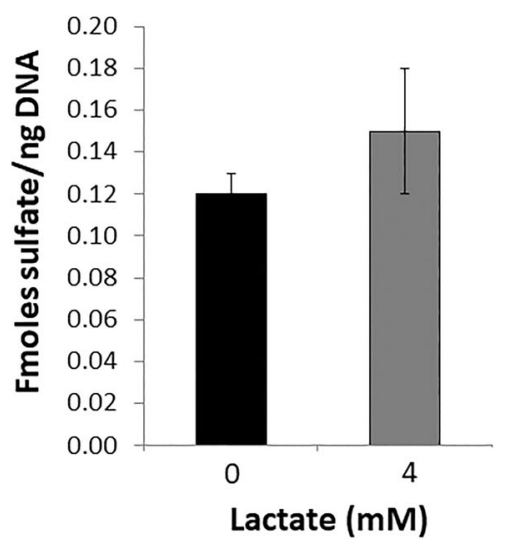

Fig. 5 Lactate-treated AF cells exhibit increased aerobic respiration and matrix protein synthesis. A Increase in in basal oxygen consumption and mitochondria ATP-link respiration in AF cells treated with lactate. Oxygen consumption rates (OCR) of AF cells were measured by Seahorse XFe96 Extracellular Flux Analyzer at basal conditions and with serial administration of $1 \mu \mathrm{M}$ oligomycin, $0.3 \mu \mathrm{M} \mathrm{FCCP,} 100 \mathrm{mM} 2 \mathrm{DG}$, and $1 \mu \mathrm{M}$ rotenone. OCR was calculated and normalized to protein amount and the results were expressed as a mean of four different samples \pm SEM. Individual parameters of OXPHOS were derived from OCR profiles of AF cells \pm lactate, as described in the "Materials and methods" section. Addition of lactate significantly increased basal OCR (A.1) and mitochondrial ATP-linked respiration (A.2). Results are expressed as mean of four different samples (derived from four rabbits) $\pm \mathrm{SEM},{ }^{*} p<0.05$. B Exogenously added lactate increases matrix protein synthesis. Rabbit AF cell cultures exposed to physiological concentration of glucose $(1 \mathrm{mM})$ in the presence or absence of $4 \mathrm{mM}$ lactate. The presence of lactate also increases protein synthesis $\left({ }^{3} \mathrm{H}\right.$-L-proline incorporation (B.1), collagen matrix synthesis $\left({ }^{3} \mathrm{H}\right.$-Lproline incorporation \& collagenase sensitive fraction (B.2), and proteoglycan synthesis $\left({ }^{35} \mathrm{~S}\right.$-sulfate incorporation (B.3). Results are expressed as mean of four different samples (derived from four rabbits) \pm SEM. ${ }^{*} p<0.05$

and metabolized via OXPHOS to generate ATPs and amino acids. We also demonstrated that lactate stimulates collagen and protein synthesis in AF cells cultured under limited nutrient, e.g. $1 \mathrm{mM}$ glucose and $1 \%$ FBS, that mimics the physiological condition. Thus, while lactate is an end-product of NP glycolysis, it represents an important biofuel for disc AF cells. Moreover, lactate utilization by AF cells can mitigate the buildup of lactate and its negative effects on NP cells, thus providing symbiotic benefits between AF and NP tissues. It should be noted that glycogen is also present in disc tissue, but it is primarily found within the NP tissue and minimally in 
the inner AF region [40]. Thus, glycogen most likely serves as a biofuel reserve for NP but not AF cells.

\section{Lactate import into AF cells}

Through radioactive and heavy isotope lactate labeling and tracing experiments using in vitro cell culture and in vivo rat models, we demonstrated that AF cells are capable of importing lactate from the extracellular environment (Figs. 2, 3, and 4, S4). Moreover, through immunoanalyses, we demonstrated that AF cells in their native tissue environment express the proper transporter required for importing lactate; rabbit AF but not NP tissue, expresses an abundance of MCT1 (Fig. 2). MCT1 serves the major physiological role in facilitating Llactate transport into or out of cells depending on their tissue niche and metabolic state. However, this bidirectionality of MCT1 is reported to shift toward primarily lactate import in oxygenated tissues with mitochondrial OXPHOS capacity, including the peripheral region of solid tumors [12, 41], heart tissue [42], red skeletal muscle [43], liver parenchymal cells, and kidney convoluted tubule cells [29]. Given the fact that AF tissue is more oxygenated because it is closer to the vasculature and that AF cells harbor active mitochondria and carry out OXPHOS [23, 44, 45], our findings strongly suggest that MCT1 is the key lactate importer in AF cells. It should be noted that MCT2 and MCT3 are the other major lactate transporters with high lactate affinity with $\mathrm{Km}$ values lower or comparable to that of MCT1 [46]. However, expression of MCT2 and MCT3 was not detectable in disc tissue (data not shown). MCT4 is another lactate transporter, but it is hypoxia-inducible and predominates over MCT1 for lactate export in hypoxic and glycolytic tissues [38].

\section{Lactate metabolism in AF cells}

Through ${ }^{13} \mathrm{C}$-lactate tracing experiments in vitro and in vivo, we demonstrated that AF cells can import and aerobically metabolize lactate (Figs. 3 and 4). Interestingly, AF cells appear to use lactate mainly for biosynthesis and OXPHOS for energy production. This is evident by our detection of ${ }^{13} \mathrm{C}$ in amino acids and TCA intermediates (Fig. 4B, Figure S4A). Interestingly, intracellular enrichment of ${ }^{13} \mathrm{C}$ on different TCA metabolites from ${ }^{13} \mathrm{C}$-lactate labeling was largely unaffected when AF cells were cultured in $1 \mathrm{mM}$ or $5 \mathrm{mM}$ glucose or in $2 \%$ versus $5 \%$ oxygen. These findings suggest uptake and aerobic metabolism of lactate by AF cells is not significantly impacted by fluctuation of glucose and oxygen as long as such fluctuation stays within disc AF tissue physiologic range for glucose (1-5 $\mathrm{mM})$ and oxygen (2$5 \%)$. Moreover, our data also demonstrate that under disc physiologic glucose concentration (1-5 mM), AF cells have similar preferences for utilizing lactate and glucose for oxidative phosphorylation and matrix synthesis (Figures S4B, S6D).

Our immunoanalyses also demonstrated that AF cells in their native tissue express the proper enzymes required for converting lactate back to pyruvate and to acetyl-CoA for OXPHOS (Figs. 2, 3, and 4). Lactate dehydrogenase (LDH), the primary enzyme that catalyzes the interconversion of lactate and pyruvate, exists in five isozymes composed of a tetramer of $\mathrm{M}$ and $\mathrm{H}$ protein subunits encoded by the LDHA and LDHB genes, respectively (Fig. 3c). Compared to NP, AF tissue expresses significantly more $\mathrm{M}$ protein that constitutes the LDH1 isozyme that preferentially converts lactate to pyruvate [34]. AF tissue, not NP, also highly expresses pyruvate dehydrogenase (PDH), the enzyme responsible for catalyzing the conversion of pyruvate to acetyl-coA for oxidative metabolism in the TCA cycle. On the other hand, AF but not NP tissue expresses low level of pyruvate dehydrogenase kinase 1 (PDK1) whose function is to inhibit PDH activity. Together, our findings support the idea that AF cells, much more so than NP cells in disc tissue, are programed to express the proper molecular machinery to import and convert lactate to acetylcoA necessary for OXPHOS.

\section{A new model of disc metabolism: lactate-dependent metabolic symbiosis}

Based on our new findings, we propose a working model of disc lactate-dependent metabolic symbiosis whereby hypoxic NP cells anaerobically convert glucose into lactate, which is then secreted and imported into neighboring cells of the more oxygenated AF tissue to be metabolized via OXPHOS (Fig. 6). For the sake of simplicity, this model illustrates the distinct metabolic features between NP and AF and highlights key transporters and enzymes most relevant for disc lactatedependent metabolic symbiosis, although we acknowledge that such simple metabolic distinction might not be representative of what actually occurs in vivo given the gradients of oxygen and nutrient concentrations that exist in disc tissue. In hypoxic NP cells, glucose is taken up via the glucose transporter Glut1 [47] and converted to pyruvate through glycolysis. Pyruvate is then converted to lactate and exported into the extracellular space via MCT4. Each of these key steps is well documented by our data and previously published literature $[4,38,47]$. Glut1 is highly expressed in NP tissue [48], as hexokinase 2 (Figure S7, Supplementary Material), a key glycolytic enzyme, confirming the glycolytic nature of NP cells $[38,45]$. Lactate export is likely mediated via MCT4 in NP cells as NP but not AF tissue highly expresses MCT4 (Fig. 3). Indeed, using transgenic MCT4 null mice, Silagi et al. recently demonstrated the important role of MCT4 as a lactate/proton co-exporter to 


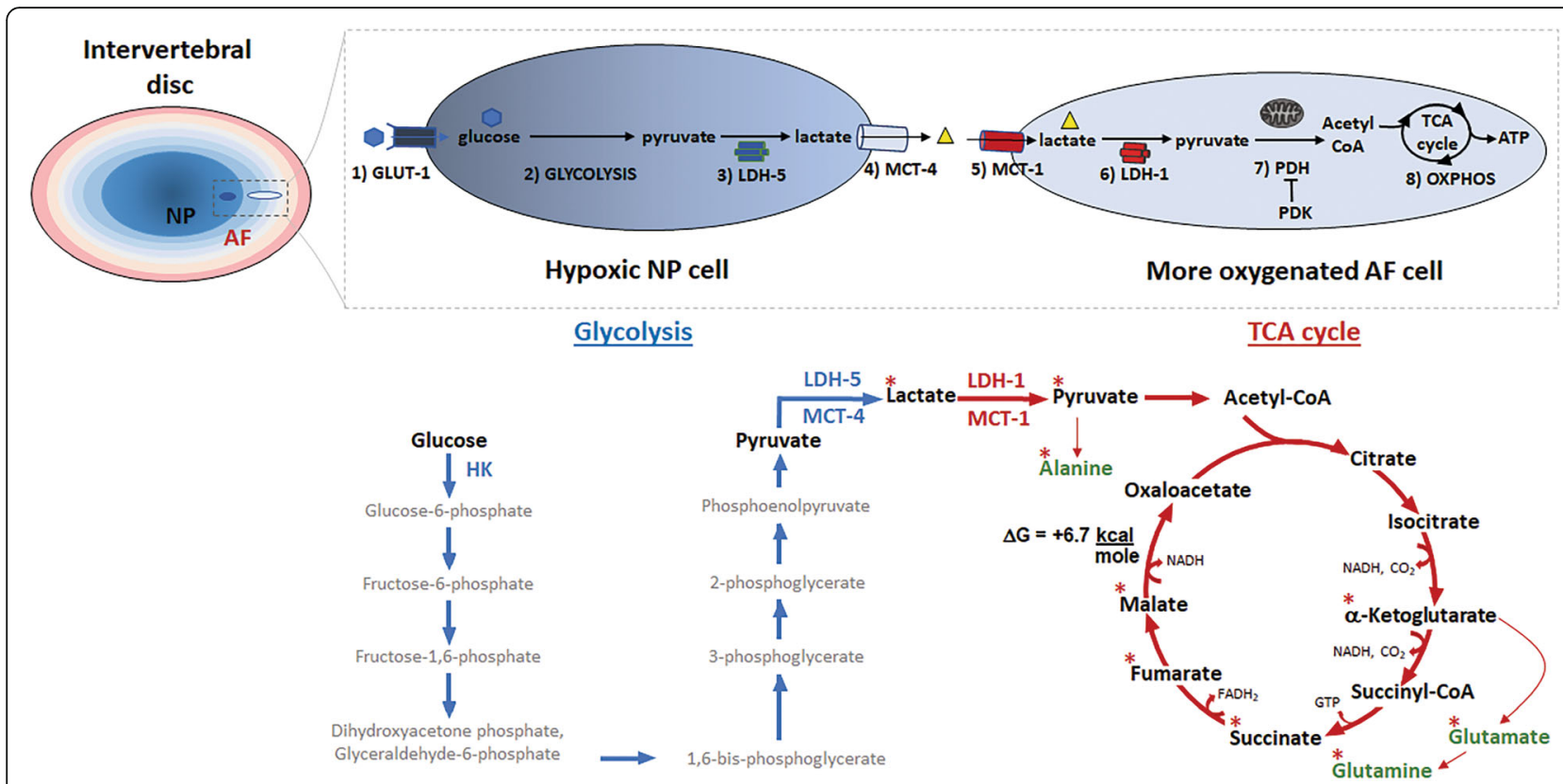

Fig. 6 Proposed model of disc lactate metabolic symbiosis. A simplified model of disc lactate-dependent metabolic symbiosis showing the major steps of glucose metabolism starting with (1) glucose uptake via the Glut1 transporter into hypoxic NP cells, (2) conversion of glucose to pyruvate by glycolysis, (3) conversion of pyruvate to lactate by LDH5, (4) export of lactate out of NP cells through MCT4, (5) import of extracellular lactate into the more oxygenated AF cells via the MCT1, (6) conversion of lactate into pyruvate by LDH1, (7) conversion of pyruvate into acetylCOA by PDH, which is negatively regulated by PDK, and (8) shuttle of acetyl-coA into the TCA cycle to generate precursors for biosynthesis and/or for oxidative phosphorylation to generate ATP. Below NP cell is shown the glycolytic pathway while below AF cell is the TCA cycle. Pyruvate to lactate converting enzyme (LDH-5), lactate exporter (MCT-4), lactate importer (MCT-1), and lactate to pyruvate converting enzyme (LDH-1) are shown. * Denotes the amino acids (green) and TCA metabolites (black) containing ${ }^{13} \mathrm{C}$ derived from the heavy isotope ${ }^{13} \mathrm{C}$-lactate label. Malate conversion to oxaloacetate is the most thermodynamically unfavorable step in the TCA cycle with the $\Delta \mathrm{G}=+6.7 \mathrm{kcal}^{\mathrm{mol}}{ }^{-}$

maintain intracellular pH homeostasis in NP tissue [38]. Our proposed role of MCT4 as a lactate exporter in the hypoxic NP is also consistent with the literature of muscle and solid tumors, which reported that MCT4 $\left(\mathrm{K}_{\mathrm{m}}\right.$ lactate $\left.\sim 25 \mathrm{mM}\right)$ is hypoxia-inducible and predominates over MCT1 $\left(\mathrm{K}_{\mathrm{m}}\right.$ lactate $\left.\sim 5 \mathrm{mM}\right)$ for lactate export in "glycolytic" tissues [34, 49]. Expression of these proteins, MCT4, Glut1, and hexokinase, are upregulated by the hypoxia-inducible factor $1 \alpha$ (HIF- $1 \alpha)$ that is constitutively active in NP [50]. Altogether, these findings demonstrate the glycolytic phenotype of NP in producing and exporting lactate.

Our study has several limitations. First, a caveat to our approach is that by relying on isotopic enrichments alone, we are limited to calculations of relative flux. As recently described, relative flux calculations can overestimate net flux due to isotopic exchange [51]. Future studies to address the net contribution of lactate to amino acid synthesis and OXPHOS will be necessary. Second, lactate flux does not occur only in the AF and NP interface; in large discs such as human lumbar discs, lactate exit and glucose entrance also occur substantially via the endplate. Nevertheless, efficient utilization of lactate by AF tissue would ensure that AF cells use less glucose, especially at the inner AF/NP interface, thereby allowing greater amount of glucose to bypass AF to diffuse into the NP to feed the cells in that disc region; this phenomenon has been previously reported in solid tumors which are anatomically analogous to disc tissue [14]. Third, our study has not established that lactate utilization as a biofuel is biologically essential. To demonstrate such is the case, AF-targeted genetic knockout of one of the lactate handling machineries, e.g. MCT-1 or LDH-B, in an in vivo model is required.

\section{Conclusions}

Our new data suggest that lactate has been overlooked as an important biofuel in disc metabolism. Importantly, our findings also indicate the existence of lactatedependent metabolic symbiosis between NP and AF of the IVD as a metabolic adaptation to efficiently recycle lactate. Such metabolic adaptation would not only prevent the accumulation of lactate as a waste product but also simultaneously generate the much-needed energy as well as precursors for biosynthesis to cells residing within the nutrient-poor disc environment. As a point of illustration, only two ATPs would be produced from glycolysis of each glucose molecule if lactate is eliminated 
as waste. This is miniscule compared to about 30 ATPs produced from one glucose if lactate is metabolized via OXPHOS.

One important implication of our model is that compromised or disrupted lactate symbiosis could contribute to metabolic disturbance and IDD. If disc lactate metabolic symbiosis is indeed determined to be vital for disc health, it will open a floodgate of new and important questions for future studies regarding disc metabolism, including identification of protein regulators and mechanistic pathways that control expression of key lactate handling molecular machinery and their enzymatic activities in lactate transport and metabolism. Verifying the importance of lactate metabolism by AF cells will guide the development of new therapeutic interventions to combat metabolic-related IDD disorders.

\section{Abbreviations}

AF: Annulus fibrosus; FBS: Fetal bovine serum; HK: Hexokinase; IDD: Intervertebral disc degeneration; IVD: Intervertebral disc; LDH: Lactate dehydrogenase; MCT: Monocarboxylate transporter; NP: Nucleus pulposus; OXPHOS: Oxidative phosphorylation; PDH: Pyruvate dehydrogenase; PDK: Pyruvate dehydrogenase kinase; PG: Proteoglycan; TCA: Tricarboxylic acid

\section{Supplementary Information}

The online version contains supplementary material available at https://doi. org/10.1186/s13075-021-02501-2.

Additional file 1: Figure S1. Lactate tolerance by AF cells in cell culture. Rabbit AF cells were grown on monolayer culture under physiologic nutrients, e.g. 1\% FBS, $1.06 \mathrm{mM}$ glucose and varying exogenously added lactate concentrations (0-20 mM), for 48 hrs. Effects of different lactate concentrations on cell density and morphology $(\mathbf{A})$ and cell viability as determined by CCK8 assay (B). Cell viability data are means \pm SEM of three independent experiments (3 rabbits). Figure S2. Lactate import into HepG2 cells. ${ }^{14} \mathrm{C}$-lactate radioactive tracing to assess lactate import into HepG2 cell cultures grown in $1 \mathrm{mM}$ glucose and varying concentrations of ${ }^{14} \mathrm{C}$-lactate $(1,4 \mathrm{mM})$ for one minute, washed with PBS, lysed and counted in scintillation fluid. Figure S3. Lactate conversion to pyruvate in AF cells in ex vivo disc organ. ${ }^{13} \mathrm{C}$-lactate tracing to pyruvate conversion in ex vivo rabbit disc organ culture containing $4 \mathrm{mM}^{13} \mathrm{C}$-lactate in the culture media. Intracellular enrichment of ${ }^{13} \mathrm{C}$ lactate or pyruvate AF cells from AF tissue of the ex vivo disc organ culture is reported as atomic percent excess (APE) of the total amount of lactate or pyruvate, e.g. 10\% APE of pyruvate indicates $10 \%$ of total pyruvate contains ${ }^{13} \mathrm{C}$. Percent (\%) APE shown. $(\mathrm{M}+1)$ indicates that one ${ }^{13} \mathrm{C}$ carbon is present on lactate or pyruvate molecule. Figure S4. Lactate uptake and conversion to TCA intermediates and amino acids in rabbit, human, and rat AF cells. $(\mathbf{A}){ }^{13} \mathrm{C}$ from rabbit AF cells cultured in $4 \mathrm{mM} 3-{ }^{13} \mathrm{C}$-lactate and $1 \mathrm{mM}$ glucose was traced to amino acids glutamate, glutamine, and alanine. (B) Preferential lactate uptake and conversion to TCA intermediates by rabbit AF cells. ${ }^{13} \mathrm{C}$ from ${ }^{13} \mathrm{C}$-Lactate or ${ }^{13} \mathrm{C}$-Glucose was traced by HRMS to TCA intermediates in rabbit AF cells grown in three different culture media. Note that ${ }^{13} \mathrm{C}$ enrichments of succinate, fumarate, and malate from $1 \mathrm{mM}{ }^{13} \mathrm{C}$-Glucose (black bars) were dramatically reduced in the presence of $4 \mathrm{mM}$ unlabeled lactate (grey bars). Consistent with this result is that ${ }^{13} \mathrm{C}$ enrichments of succinate, fumarate, and malate from $4 \mathrm{mM}{ }^{13} \mathrm{C}$-Lactate were not affected in $1 \mathrm{mM}$ unlabeled glucose (white bars), indicating that AF cells preferentially utilize lactate when grown under physiologic nutrient condition of $1 \mathrm{mM}$ glucose and $4 \mathrm{mM}$ lactate. (C) ${ }^{13} \mathrm{C}$ from human AF cells cultured in $4 \mathrm{mM} 3-{ }^{13} \mathrm{C}$-lactate was traced to the TCA intermediate malate and the amino acid glutamate. (D) Caudal discs of Fischer 344 rats were injected with $3{ }^{13} \mathrm{C}$-lactate (see method) and ${ }^{13} \mathrm{C}$ was traced to lactate, malate, and glutamate in the AF tissues 3 days post injection. Intracellular enrichment of ${ }^{13} \mathrm{C}$ on different

metabolites in AF cells was measured in APE or atom percent excess. Data are means \pm SEM of three independent experiments (three rats) for D, four experiments for C (four human disc specimen), and four experiments for A, B (four rabbits). Figure S5. Pharmacological profiling of OCR of rabbit AF cells in the absence and presence of lactate. OCR of AF cells (A) were measured by Seahorse XFe96 Extracellular Flux Analyzer at basal conditions and with serial administration of $1 \mu \mathrm{M}$ oligomycin, 0.3 $\mu \mathrm{M}$ FCCP, $100 \mathrm{mM}$ 2DG and $1 \mu \mathrm{M}$ rotenone. OCR was calculated and normalized to protein amount and the results were expressed as a mean of four different samples \pm SEM. Individual parameters of OXPHOS (B) were derived from OCR profiles of AF cells \pm lactate, as described in Materials and Methods. Addition of lactate did not significantly affect respiration reserved capacity (Res Cap), respiration total capacity (Tot Cap), non-glucose respiration (NG OCR) and non-mitochondrial oxygen consumption (NMR). Results are expressed as mean of four different samples (derived from four rabbits) $\pm \mathrm{SEM},{ }^{*} p<0.05$. Figure S6. Exogenously added lactate decreases matrix protein synthesis. Rabbit NP cell cultures exposed to physiological concentration of glucose $(1 \mathrm{mM})$ in the presence or absence of $4 \mathrm{mM}$ lactate. The presence of lactate decreases overall proteoglycan synthesis $\left({ }^{35} \mathrm{~S}\right.$-sulfate incorporation, $\left.p=0.64, \mathbf{A}\right)$, collagen matrix synthesis $\left({ }^{3} \mathrm{H}\right.$-Lproline incorporation \& collagenase sensitive fraction, $p=0.21$, B), and protein synthesis ( ${ }^{3} \mathrm{H}$-L-proline incorporation, $p=$ 0.1 , C). D) Rabbit AF cells grown at $5 \% \mathrm{O}_{2}$ in $5 \mathrm{mM}$ glucose, $5 \mathrm{mM}$ lactate, or $1 \mathrm{mM}$ glucose $+4 \mathrm{mM}$ lactate generated similar levels of total protein (black bars) and collagen (grey bars) synthesis. Results are expressed as mean of four different samples (derived from four rabbits) \pm SEM. Figure S7. HK2 protein expression in AF and NP tissues. Western blot of hexokinase 2 (HK2) in rabbit AF and NP tissue protein extract $(\mathbf{A})$ and their protein levels were quantified by normalizing to $\beta$-actin as loading control (B). Data are means \pm SD of three independent experiments (three rabbits). ${ }^{*} p<0.05$

\section{Acknowledgements}

We thank Jessa Darwin for her editorial support. We gratefully acknowledge the technical support from the Ferguson Laboratory for Orthopaedic and Spine Research, University of Pittsburgh.

\section{Authors' contributions}

J.K., M.J., G.S., and N.V. designed research; D.W., R.H., C.H., C.Z., and S.W. performed research; B.VH., J.L., S.W., and N.V. analyzed data; N.V. and G.S. wrote the paper. The authors read and approved the final manuscript.

\section{Funding}

The authors gratefully acknowledge the following funding sources that enabled the successful completion of this project: The National Institute of Health (NIA R01 AG044376 to NV; NIDDK R01 DK114012 and DK119627 to MJJ; R33ES025606 to B.V.H. NIHS100D023402 (SGW)), the SPRIG Pilot Award of the UPMC Aging Institute the Department of Orthopaedic Surgery, and the Albert B. Ferguson, Jr. MD Fund of the Pittsburgh Foundation (AD201898524), S100D023402 (SGW).

\section{Availability of data and materials}

All data generated or analyzed during this study are included in this published article [and its supplementary information files].

\section{Declarations}

\section{Ethics approval and consent to participate}

The experimental protocol for collecting and processing disc tissues isolated from patients underwent surgeries for disc degeneration was approved by the human subjects Institutional Review Board at the University of Pittsburgh. Animals used in this study were performed in full compliance with approved protocol from our Institutional Animal Care and Use Committee.

Consent for publication Not applicable. 


\section{Competing interests}

The authors declare that they have no competing interests.

\section{Author details}

'Department of Orthopaedic Surgery, Ferguson Laboratory for Orthopedic and Spine Research, University of Pittsburgh, 200 Lothrop Street, E1644 Biomedical Science Tower, Pittsburgh, PA 15261, USA. ${ }^{2}$ University of Pittsburgh Medical Center Enterprises, Pittsburgh, PA 15213, USA. ${ }^{3}$ Tianjin Hospital, 406 Jiefang South Road Hexi District, Tianjin, PR China. ${ }^{4}$ Department of Pharmacology and Chemical Biology, University of Pittsburgh, 5117 Centre Avenue, Pittsburgh, PA 15213, USA. ${ }^{5}$ Health Sciences Metabolomics and Lipidomics Core, University of Pittsburgh, Pittsburgh, PA, USA. 'Department of Medicine, Division of Endocrinology and Metabolism, University of Pittsburgh, Pittsburgh, PA, USA. ${ }^{7}$ Center for Metabolism and Mitochondrial Medicine, University of Pittsburgh, Pittsburgh, PA 15213, USA. ${ }^{8}$ Department of Orthopedics, Brigham and Women's Hospital, School of Medicine, Harvard University, 75 Francis Street, Boston, MA 02115, USA. ${ }^{9}$ Department of Physical Medicine and Rehabilitation, University of Pittsburgh School of Medicine, Pittsburgh, PA 15219, USA.

Received: 15 May 2020 Accepted: 3 April 2021

\section{Published online: 21 May 2021}

\section{References}

1. Luo X, Pietrobon R, Sun SX, Liu GG, Hey L. Estimates and patterns of direct health care expenditures among individuals with back pain in the United States. Spine. 2004;29(1):79-86. https://doi.org/10.1097/01.BRS.0000105527.13 866.0F.

2. Urban JP, Smith S, Fairbank JC. Nutrition of the intervertebral disc. Spine (Phila Pa 1976). 2004;29(23):2700-9. https://doi.org/10.1097/01.brs.00001464 99.97948.52.

3. Huang YC, Urban JP, Luk KD. Intervertebral disc regeneration: do nutrients lead the way? Nat Rev Rheumatol. 2014;10(9):561-6. https://doi.org/10.1038/ nrrheum.2014.91.

4. Bartels EM, Fairbank JC, Winlove CP, Urban JP. Oxygen and lactate concentrations measured in vivo in the intervertebral discs of patients with scoliosis and back pain. Spine (Phila Pa 1976). 1998:23:1-7; discussion 8.

5. Holm S, Maroudas A, Urban JP, Selstam G, Nachemson A. Nutrition of the intervertebral disc: solute transport and metabolism. Connect Tissue Res. 1981;8(2):101-19. https://doi.org/10.3109/03008208109152130.

6. Gilbert HTJ, Hodson N, Baird P, Richardson SM, Hoyland JA. Acidic pH promotes intervertebral disc degeneration: acid-sensing ion channel -3 as a potential therapeutic target. Sci Rep. 2016;6(1):37360. https://doi.org/10.103 8/srep37360.

7. Ohshima $\mathrm{H}$, Urban JP. The effect of lactate and $\mathrm{pH}$ on proteoglycan and protein synthesis rates in the intervertebral disc. Spine (Phila Pa 1976). 1992; 17(9):1079-82. https://doi.org/10.1097/00007632-199209000-00012.

8. Fu J, Yu W, Jiang D. Acidic pH promotes nucleus pulposus cell senescence through activating the p38 MAPK pathway. Biosci Rep. 2018;38:1-8.

9. Ngo K, Patil P, McGowan SJ, Niedernhofer LJ, Robbins PD, Kang J, Sowa G, Vo N. Senescent intervertebral disc cells exhibit perturbed matrix homeostasis phenotype. Mech Ageing Dev. 2017;166:16-23. https://doi. org/10.1016/j.mad.2017.08.007.

10. Urban JP. The role of the physicochemical environment in determining disc cell behaviour. Biochem Soc Trans. 2002;30(6):858-64. https://doi.org/10.1 042/bst0300858

11. Bibby SR, Urban JP. Effect of nutrient deprivation on the viability of intervertebral disc cells. Eur Spine J. 2004;13(8):695-701. https://doi.org/10.1 007/s00586-003-0616-x.

12. Sonveaux P, Végran F, Schroeder T, Wergin MC, Verrax J, Rabbani ZN, de Saedeleer CJ, Kennedy KM, Diepart C, Jordan BF, Kelley MJ, Gallez B, Wahl ML, Feron O, Dewhirst MW. Targeting lactate-fueled respiration selectively kills hypoxic tumor cells in mice. J Clin Invest. 2008;118(12):3930-42. https:// doi.org/10.1172/JCl36843.

13. Kennedy KM, Scarbrough PM, Ribeiro A, Richardson R, Yuan H, Sonveaux P, Landon CD, Chi JT, Pizzo S, Schroeder T, Dewhirst MW. Catabolism of exogenous lactate reveals it as a legitimate metabolic substrate in breast cancer. PLoS One. 2013;8(9):e75154. https://doi.org/10.1371/journal.pone. 0075154.
14. Feron O. Pyruvate into lactate and back: from the Warburg effect to symbiotic energy fuel exchange in cancer cells. Radiother Oncol. 2009;92(3): 329-33. https://doi.org/10.1016/j.radonc.2009.06.025.

15. Brooks GA. Cell-cell and intracellular lactate shuttles. J Physiol. 2009;587(23): 5591-600. https://doi.org/10.1113/jphysiol.2009.178350.

16. Gladden LB. Lactate metabolism: a new paradigm for the third millennium. J Physiol. 2004;558(1):5-30. https://doi.org/10.1113/jphysiol.2003.058701.

17. Magistretti PJ. Neuron-glia metabolic coupling and plasticity. J Exp Biol. 2006;209(12):2304-11. https://doi.org/10.1242/jeb.02208.

18. Skelton MS, Kremer DE, Smith EW, Gladden LB. Lactate influx into red blood cells of athletic and nonathletic species. Am J Phys. 1995;268:R1121-8.

19. Brooks GA. Intra- and extra-cellular lactate shuttles. Med Sci Sports Exerc. 2000;32(4):790-9. https://doi.org/10.1097/00005768-200004000-00011.

20. Nakajima EC, Van Houten B. Metabolic symbiosis in cancer: refocusing the Warburg lens. Mol Carcinog. 2013;52(5):329-37. https://doi.org/10.1002/ mc.21863.

21. Alves TC, Pongratz RL, Zhao X, Yarborough O, Sereda S, Shirihai O, Cline GW, Mason G, Kibbey RG. Integrated, step-wise, mass-isotopomeric flux analysis of the TCA cycle. Cell Metab. 2015;22(5):936-47. https://doi.org/10.1 016/j.cmet.2015.08.021

22. Patil P, Dong Q, Wang D, Chang J, Wiley C, Demaria M, Lee J, Kang J, Niedernhofer LJ, Robbins PD, Sowa G, Campisi J, Zhou D, Vo N. Systemic clearance of p16(INK4a)-positive senescent cells mitigates age-associated intervertebral disc degeneration. Aging Cell. 2019;18(3):e12927. https://doi. org/10.1111/acel.12927.

23. Hartman R, et al. Age-dependent changes in intervertebral disc cell mitochondria and bioenergetics. Eur Cells Mater. 2018;36:171-83. https://doi. org/10.22203/eCM.v036a13.

24. de Moura MB, Van Houten B. Bioenergetic analysis of intact mammalian cells using the seahorse XF24 extracellular flux analyzer and a luciferase ATP assay. Methods Mol Biol. 2014;1105:589-602. https://doi.org/10.1007/978-162703-739-6_40.

25. Gilbertson L, Ahn SH, Teng PN, Studer RK, Niyibizi C, Kang JD. The effects of recombinant human bone morphogenetic protein-2, recombinant human bone morphogenetic protein-12, and adenoviral bone morphogenetic protein-12 on matrix synthesis in human annulus fibrosis and nucleus pulposus cells. Spine J. 2008;8(3):449-56. https://doi.org/10.1016/j.spinee.2 006.11.006.

26. Boubriak O, Zhou S, Urban J. Oxygen metabolism of intervertebral disc cells: comparison between cells from the bovine outer annulus and nucleus pulposus. In: International Society for the Study of the Lumbar Spine Conference Special poster presentation (SP36); 2010.

27. Shim EK, Lee JS, Kim DE, Kim SK, Jung BJ, Choi EY, Kim CS. Autogenous mesenchymal stem cells from the vertebral body enhance intervertebral disc regeneration via paracrine interaction: an in vitro pilot study. Cell Transplant. 2016;25(10):1819-32. https://doi.org/10.3727/09636891 6X691420.

28. Miguelez-Rivera L, et al. Immunomodulation of mesenchymal stem cells in discogenic pain. Spine J. 2018;18(2):330-42. https://doi.org/10.1016/j. spinee.2017.09.002.

29. Halestrap AP, Meredith D. The SLC16 gene family-from monocarboxylate transporters (MCTs) to aromatic amino acid transporters and beyond. Pflugers Arch. 2004;447(5):619-28. https://doi.org/10.1007/s00424-003-1 067-2.

30. Halestrap AP, Wilson MC. The monocarboxylate transporter family--role and regulation. IUBMB Life. 2012;64(2):109-19. https://doi.org/10.1002/ iub. 572 .

31. Ullah MS, Davies AJ, Halestrap AP. The plasma membrane lactate transporter MCT4, but not MCT1, is up-regulated by hypoxia through a HIF1alpha-dependent mechanism. J Biol Chem. 2006;281(14):9030-7. https:// doi.org/10.1074/jbc.M511397200.

32. Baltazar F, Pinheiro C, Morais-Santos F, Azevedo-Silva J, Queirós O, Preto A, Casal M. Monocarboxylate transporters as targets and mediators in cancer therapy response. Histol Histopathol. 2014;29(12):1511-24. https://doi.org/1 $0.14670 / \mathrm{HH}-29.1511$

33. Valvona CJ, Fillmore HL, Nunn PB, Pilkington GJ. The regulation and function of lactate dehydrogenase a: therapeutic potential in brain tumor. Brain Pathol. 2016;26(1):3-17. https://doi.org/10.1111/bpa.12299.

34. Draoui N, Feron O. Lactate shuttles at a glance: from physiological paradigms to anti-cancer treatments. Dis Model Mech. 2011;4(6):727-32. https://doi.org/10.1242/dmm.007724. 
35. Voet DVJ, Pratt CW. Fundamentals of Biochemistry: Life at the Molecular Level (4th ed.). Hoboken: Wiley; 2015. p. 574-5. ISBN 978-570-470-5478454787.

36. Plaitakis A, Latsoudis H, Spanaki C. The human GLUD2 glutamate dehydrogenase and its regulation in health and disease. Neurochem Int. 2011;59(4):495-509. https://doi.org/10.1016/j.neuint.2011.03.015.

37. Qian W, Van Houten B. Alterations in bioenergetics due to changes in mitochondrial DNA copy number. Methods. 2010;51(4):452-7. https://doi. org/10.1016/j.ymeth.2010.03.006.

38. Silagi ES, Novais EJ, Bisetto S, Telonis AG, Snuggs J, le Maitre CL, Qiu Y, Kurland IJ, Shapiro IM, Philp NJ, Risbud MV. Lactate efflux from intervertebral disc cells is required for maintenance of spine health. J Bone Miner Res. 2019:35(3):550-70. https://doi.org/10.1002/jbmr.3908.

39. Risbud MV, Schipani E, Shapiro IM. Hypoxic regulation of nucleus pulposus cell survival: from niche to notch. Am J Pathol. 2010;176(4):1577-83. https:// doi.org/10.2353/ajpath.2010.090734.

40. Holm S, Selstam G, Nachemson A. Carbohydrate metabolism and concentration profiles of solutes in the canine lumbar intervertebral disc. Acta Physiol Scand. 1982;115(1):147-56. https://doi.org/10.1111/j.1748-1716.1 982.tb07057.x.

41. De Saedeleer CJ, et al. Lactate activates HIF-1 in oxidative but not in Warburg-phenotype human tumor cells. PLoS One. 2012;7(10):e46571. https://doi.org/10.1371/journal.pone.0046571.

42. Bonen A. The expression of lactate transporters (MCT1 and MCT4) in heart and muscle. Eur J Appl Physiol. 2001;86(1):6-11. https://doi.org/10.1007/ s004210100516.

43. Juel C, Halestrap AP. Lactate transport in skeletal muscle - role and regulation of the monocarboxylate transporter. J Physiol. 1999;517(Pt 3): 633-42. https://doi.org/10.1111/j.1469-7793.1999.0633s.X.

44. Gruber HE, Watts JA, Riley FE, Fulkerson MB, Norton HJ, Hanley EN Jr. Mitochondrial bioenergetics, mass, and morphology are altered in cells of the degenerating human annulus. J Orthop Res. 2013;31(8):1270-5. https:// doi.org/10.1002/jor.22361.

45. Ishihara H, Urban JP. Effects of low oxygen concentrations and metabolic inhibitors on proteoglycan and protein synthesis rates in the intervertebral disc. J Orthop Res. 1999;17(6):829-35. https://doi.org/10.1002/jor.11001 70607.

46. Perez-Escuredo J, et al. Monocarboxylate transporters in the brain and in cancer. Biochim Biophys Acta. 2016;1863(10):2481-97. https://doi.org/10.101 6/j.bbamcr.2016.03.013

47. Rajpurohit R, Risbud MV, Ducheyne P, Vresilovic EJ, Shapiro IM. Phenotypic characteristics of the nucleus pulposus: expression of hypoxia inducing factor-1, glucose transporter-1 and MMP-2. Cell Tissue Res. 2002;308(3):4017. https://doi.org/10.1007/s00441-002-0563-6.

48. Richardson SM, Knowles R, Tyler J, Mobasheri A, Hoyland JA. Expression of glucose transporters GLUT-1, GLUT-3, GLUT-9 and HIF-1alpha in normal and degenerate human intervertebral disc. Histochem Cell Biol. 2008;129(4):50311. https://doi.org/10.1007/s00418-007-0372-9.

49. Dimmer KS, Friedrich B, Lang F, Deitmer JW, Broer S. The low-affinity monocarboxylate transporter MCT4 is adapted to the export of lactate in highly glycolytic cells. Biochem J. 2000;350(Pt 1):219-27. https://doi.org/10.1 042/bj3500219.

50. Fujita $\mathrm{N}$, et al. Expression of prolyl hydroxylases (PHDs) is selectively controlled by HIF-1 and HIF-2 proteins in nucleus pulposus cells of the intervertebral disc: distinct roles of PHD2 and PHD3 proteins in controlling HIF1a activity in hypoxia. J Biol Chem. 2012;287:16975-86.

51. Ying M, Guo C, Hu X. The quantitative relationship between isotopic and net contributions of lactate and glucose to the TCA cycle. J Biol Chem. 2019;294;9615-30.

\section{Publisher's Note}

Springer Nature remains neutral with regard to jurisdictional claims in published maps and institutional affiliations.

Ready to submit your research? Choose BMC and benefit from:

- fast, convenient online submission

- thorough peer review by experienced researchers in your field

- rapid publication on acceptance

- support for research data, including large and complex data types

- gold Open Access which fosters wider collaboration and increased citations

- maximum visibility for your research: over $100 \mathrm{M}$ website views per year

At $\mathrm{BMC}$, research is always in progress.

Learn more biomedcentral.com/submissions 